\title{
An Interdisciplinary Experimental Engineering Projects Course Development
}

\section{Dr. Faruk Yildiz, Sam Houston State University}

Faruk Yildiz is currently an Associate Professor of Engineering Technology at Sam Houston State University. His primary teaching areas are in Electronics, Computer Aided Design (CAD), and Alternative Energy Systems. Research interests include: low power energy harvesting systems, renewable energy technologies and education.

\section{Mr. Keith L. Coogler, Sam Houston State University}

Dr. Keith L. Coogler is an instructor of engineering technology at Sam Houston State University. He received a BS in Design \& Development and holds a MA in Industrial Education and Ed.D. in Higher Education from Texas A\&M University - Commerce. His primary teaching area is Construction Management. Research interests include: automation, electronics, alternative energy, and "green" construction. 


\title{
An Interdisciplinary Experimental Engineering Project Course Development
}

\begin{abstract}
The Engineering Technology (ET) program is one of several unique programs at Sam Houston State University. The program offers six Bachelor of Science (BS) Major degrees and a variety of courses for a BS Minor. The BS degrees offered in the program are: (a) Engineering Technology-Electronics; (b) Engineering Technology-Safety Management; (c) Construction Management; (d) Design and Development; (e) Electronics and Computer Engineering Technology; and (f) Industrial Education. All the students enrolled in one of these degree programs must take the same major core courses as well as the degree-specific courses as part of curriculum requirements. The common degree specific courses include Circuits, Engineering Graphics, Leadership and Management, Industrial Safety, etc. With these degree-specific requirements, students learn common content for ET degrees. Each of the six degrees require students to declare a minor in order to reach 120/123 hours as part of the curriculum requirement for graduation. In most cases, students select a minor from ET degrees, but any minor is allowed for students to declare (e.g., General Business). The goal of this interdisciplinary course is to engage ET students in engineering-related interdisciplinary projects. The new proposed course (junior/senior standing) gives an opportunity to those students majoring and minoring in ETrelated degrees to share and advance their knowledge with other students by working on an interdisciplinary project. Projects are assigned either by the course instructor or proposed by the students. This course design centers on its uniqueness, when compared to a standard capstone design course. The nature of the projects, student feedback, challenges, and outcomes/results are obtained through by implementation of the course. A comparison of the Interdisciplinary Experimental Engineering Project Course to a capstone course is offered in this paper.
\end{abstract}

\section{Introduction}

Most engineering and technology programs require their undergraduate students to take a senior design/capstone course to complete the degree. Most capstone courses are yearlong or a semester long, are specific to the student's major, and are designed to demonstrate, in some way, the student's knowledge of the discipline. To fulfill the requirements of a capstone course, the student accomplishes a field-specific project by herself/himself and is required to prepare a paper, a presentation, and/or poster to present the project before a group of peers. In some cases, industrial advisory board members are invited to the project presentation at the end of the course period [1-4].

In the 2015-2016 Criteria for Accrediting Engineering and Technology Programs published by Accreditation Board for Engineering and Technology, Inc. (ABET), Criterion 3(d) states that students must have an ability to function within multi-disciplinary teams; Criterion 4 states that students must be prepared for engineering and technology practice through the curriculum, to include a culminating major design experience based on the knowledge and skills acquired in earlier course work. This design project must incorporate appropriate engineering standards and multiple realistic constraints. In response to Criteria 3(d) and 4, many institutions have incorporated one or more team-oriented senior design courses into their program curricula [5-6] 
As part of the ABET requirement, students from ABET accredited programs were enrolled in a single-design project course starting in the early 1990s. The completion of the senior design project and course constituted success in the required element. Students accomplished their projects individually until ABET attention to industrial concerns increased. ABET realized the importance of working as teams, since engineers often work together to accomplish a design goal [6-7].

Virginia Tech and the University of Hartford invited industry partners to be part of a capstone design-project conducted jointly by research teams at the two institutions. The involvement of an industry partner ensures that projects last several years. This project was a multi-year project and its purpose was to help increase graduating engineers' abilities to work within interdisciplinary teams. As a result, the research partners also developed a summer program to ensure a smooth transition between groups of graduating seniors [8].

A similar example of an interdisciplinary engineering capstone project was a capstone class that combined electrical and computer engineering, industrial and manufacturing engineering, and mechanical engineering programs; the students worked as teams on a common project. Students were divided into groups from each of these degrees. Each team worked on the same project and were responsible for the design, development, and manufacturing of a working robot. At the end of the projects, faculty and invited guests assessed the project's success based on knowledge gained, coordination, team participation, and leadership skills [9].

During the Fall 2016 semester at Sam Houston State University, a course was offered to give students majoring and minoring in ET-related degrees an opportunity to share and advance their knowledge with other students by engaging the ET students in engineering-related interdisciplinary projects. Students volunteered for one of six different instructor-assigned projects based on their interest and knowledge of the project and were challenged to accomplish the project goals as part of a team. Student assessment was based on their group's project presentation, project poster, project paper, and time spent in the laboratory environment. The class was evaluated by the professor to assess the students' success in learning and the effectiveness of resources that may be required for future engineering-related interdisciplinary classes.

\section{Objectives}

The main objective of the projects in this course is for interdisciplinary students to work as teams to develop and/or improve hands-on skills as they work with other students from different fields of study. The projects are assigned to obtain objectives which involve the design and development of a variety of engineering and technology-related projects in order to fulfill the educational goals of their field of studies. Students are also tasked to learn how to work effectively with others as a team and to apply what they have learned from their field of study.

\section{Course Description and Grading Scale}

The course is offered under a special topics course which can have any title related to engineering/industrial technology fields. Fall 2016, a course titled "Experimental Engineering 
Projects" was developed and offered to any engineering technology (ET) major and minor student. The goal of this course was to engage ET students in engineering-related interdisciplinary projects. There were 19 students from six different majors enrolled in the course, and the students completed six different instructor-assigned projects. Each group consisted of different major and minor students. Students volunteered for each project based on their backgrounds and abilities. Grading for this project was based on following items showed in Table 1.

Table 1. Grading Scale

\begin{tabular}{|l|c|}
\hline Project Presentation (Rating from Students) & $15 \%$ \\
\hline Project Presentation (Instructor Rating) & $15 \%$ \\
\hline Project Presentation (Instructor Rating for Individual Students) & $15 \%$ \\
\hline Project Paper & $25 \%$ \\
\hline Project Poster & $20 \%$ \\
\hline Attendance, Observed Performance, Attitude & $10 \%$ \\
\hline Total & $100 \%$ \\
\hline
\end{tabular}

\section{Student Information}

Nineteen students enrolled in the class for the Fall 2016 semester. During the first class-day, students were asked to list their majors/minors and some of the core and major courses they had taken. This step was necessary to diversify student groups and to ensure that students were distributed based on the specific projects. The instructor listed potential projects for the students and created the teams based on student interests and majors (Table 2).

Table 2. Student Major and Minor Information

\begin{tabular}{|c|c|c|c|c|c|c|c|c|}
\hline Student & Major & Minor & \multicolumn{6}{|c|}{ Classes Taken } \\
\hline & & & 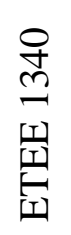 & $\begin{array}{l}\overline{0} \\
\stackrel{0}{0} \\
\hat{\theta} \\
\stackrel{\theta}{0}\end{array}$ & 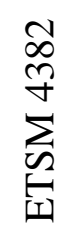 & 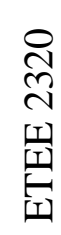 & 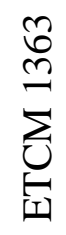 & 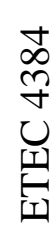 \\
\hline Student 1 & ETEE & ETDD & $\mathrm{X}$ & $\mathrm{X}$ & $\mathrm{X}$ & $\mathrm{X}$ & & $\mathrm{X}$ \\
\hline Student 2 & ETSM & ETCM & $X$ & $\mathrm{X}$ & $\mathrm{X}$ & & $\mathrm{X}$ & \\
\hline Student 3 & ETEE & AGET & $\mathrm{X}$ & $\mathrm{X}$ & & $\mathrm{X}$ & $\mathrm{X}$ & $\mathrm{X}$ \\
\hline Student 4 & ECET & & $\mathrm{X}$ & $\mathrm{X}$ & & & & \\
\hline Student 5 & ETEE & CRIM JUST & $\mathrm{X}$ & $\mathrm{X}$ & & $\mathrm{X}$ & $\mathrm{X}$ & $\mathrm{X}$ \\
\hline Student 6 & ECET & & $\mathrm{X}$ & $\mathrm{X}$ & & $\mathrm{X}$ & & \\
\hline Student 7 & ETEC & ETDD & $\mathrm{X}$ & $\mathrm{X}$ & & & & $\mathrm{X}$ \\
\hline Student 8 & ETEE & GEN BUSI & $X$ & $\mathrm{X}$ & $\mathrm{X}$ & $\mathrm{X}$ & & $\mathrm{X}$ \\
\hline Student 9 & ETSM & GEN BUSI & $\mathrm{X}$ & $\mathrm{X}$ & $\mathrm{X}$ & $\mathrm{X}$ & $\mathrm{X}$ & $X$ \\
\hline Student 10 & ETEE & COSC & $X$ & $\mathrm{X}$ & & $\mathrm{X}$ & & \\
\hline Student 11 & ETSM & ETCM & $\mathrm{X}$ & $\mathrm{X}$ & $\mathrm{X}$ & $\mathrm{X}$ & $\mathrm{X}$ & $\mathrm{X}$ \\
\hline
\end{tabular}




\begin{tabular}{|l|l|l|l|l|l|l|l|l|}
\hline Student 12 & ECET & & X & X & & X & & \\
\hline Student 13 & ECET & & X & X & & & & \\
\hline Student 14 & ECEE & ETDD & X & X & & X & & \\
\hline Student 15 & ECET & & X & X & & X & & \\
\hline Student 16 & ETEE & ETDD & X & X & X & & & \\
\hline Student 17 & ECET & & X & X & & X & & \\
\hline Student 18 & ECET & & $X$ & $X$ & & & & \\
\hline Student 19 & ETEC & ETCM & X & X & X & & X & \\
\hline
\end{tabular}

ETEC-Engineering Technology

ETDD—Design and Development

ETCM - Construction Management

ECET-Electronics and Computer Engineering Technology (no minor)

ETSM-Engineering Technology-Safety Management

ETEE-Engineering Technology-Electronics Technology

AGET-Agricultural Engineering Technology

COSC - Computer Information Science

\section{Resource Availability and Management}

The course took place in a 10,000 sq. ft. satellite technology building which houses metal/wood working machinery, a small scale foundry, classroom space with computers, soldering and welding equipment, tools, etc. The lectures were delivered in the classroom and students were asked to conduct specific online research using the computers. Two of the senior students from the Engineering Technology program assisted the course instructor during the implementation of the projects. These two senior students spent $4-5$ hours per-week to help the students during and outside of the class times. The lab coordinator also assisted teams outside of class time to work on their projects. The lab coordinator spent average 6-7 hours every week to help students. The course instructor was available to students by an appointment outside of the class time. There was no budget allocated for this course for material/supply purchase. However, the course instructor let student teams use the instructor's lab resource annual budget for materials purchases. Each team had US $\$ 250$ allocation, for a total of US $\$ 1500$ for the entire class; some of the teams decided to use their own money for minor materials purchase. Students were encouraged to pursue material and supply donations from local business. One of the teams received free service from a local discount tire shop to fix wheel problems on their electric car project. This group also received a major discount from a battery supply store to replace old batteries in the electric car.

There was no textbook required for the course. However, the course instructor plans to adapt a textbook as a future goal for the class. The textbook will be required to give an overview of the research design and methods, project management, quality control, ways to encourage team work, tips for the team leader, suggestions for sharing certain duties for a successful project, project reporting, cost estimation, resource management, prototyping, literature review, the patent process, etc. The course instructor used a variety of resources for the initial courses to cover these topics but realized that the assessment of the specific topics are difficult without the use of a textbook. 


\section{Projects}

The projects identified by the course instructor were assigned based on student interests. Some of the projects in the list were incomplete projects from previous semesters. Students were supervised by a teaching assistant and two instructors during the semester. Materials and supplies were purchased by the course instructor's departmental budget. Table 3 shows a list of the projects and the assigned students with their majors and minors. Later in the semester, two students changed their projects and joined a team with a different project after they had received course instructor approval. One team finished two projects during the semester. However, the team presented only one of the projects at the end of the semester.

Table 3. Project List and Assigned Students

\begin{tabular}{|c|c|c|c|}
\hline Project Topic & Students & $\begin{array}{c}\text { Student } \\
\text { Majors/Minors }\end{array}$ & $\begin{array}{l}\text { Team } \\
\text { Leader }\end{array}$ \\
\hline \multirow{4}{*}{$\begin{array}{l}\text { Solar Photovoltaic Grid-Tied Energy } \\
\text { Laboratory Equipment }\end{array}$} & Student 1 & ECET & \multirow{4}{*}{ Student 4} \\
\hline & Student 2 & ETEE/AGET & \\
\hline & Student 3 & ETEC/ETDD & \\
\hline & Student 4 & ETEE/COSC & \\
\hline \multirow[t]{3}{*}{ Wind Energy Training Unit Optimization } & Student 5 & ECET & \multirow[t]{3}{*}{ Student 5} \\
\hline & Student 6 & ETEC/ETDD & \\
\hline & Student 7 & ETEC/Management & \\
\hline \multirow[t]{3}{*}{ Electric Car Technology } & Student 8 & ECET & \multirow[t]{3}{*}{ Student 9} \\
\hline & Student 9 & ETEC/ETDD & \\
\hline & Student 10 & ETEC/ETCM & \\
\hline \multirow[t]{4}{*}{ Energy Generating Bicycle } & Student 11 & ETEE/Crim. Justice & \multirow[t]{4}{*}{ Student 11} \\
\hline & Student 12 & ETEC/Gen. Business & \\
\hline & Student 13 & ECET & \\
\hline & Student 14 & ECET & \\
\hline \multirow{3}{*}{$\begin{array}{l}\text { Energy Efficient Construction Materials } \\
\text { and Instrumentation Study }\end{array}$} & Student 15 & ETSM/ETCM & \multirow{3}{*}{ Student 17} \\
\hline & Student 16 & ETEC/ETCM & \\
\hline & Student 17 & ECET & \\
\hline \multirow[t]{2}{*}{ Hydrogen Unmanned All-Terrain Vehicle } & Student 18 & ECET & \multirow[t]{2}{*}{ Student 18} \\
\hline & Student 19 & ETDD/ETCM & \\
\hline \multirow{3}{*}{$\begin{array}{l}\text { Bracket Design for Two Different-Size } \\
\text { Inverter Installations }\end{array}$} & Student 5 & ECET & \multirow[t]{3}{*}{ Student 5} \\
\hline & Student 6 & ETEC/ETDD & \\
\hline & Student 7 & ETEC/Management & \\
\hline
\end{tabular}

Students were provided time logs (Appendix A) to record the amount of time they spent in the laboratory environment outside of the class time. Students were required to use laboratory resources for their projects with their team members. Every week, the course instructor or teaching assistant approved time logs for further course credit. Based on the time logs, the time spent outside of the class averaged about 3 hours (weekly). Some of the students failed to get timely signatures (weekly) from the lab coordinator and/or instructor for their time spend outside 
of the class time; in these cases, the time logs were not accepted. There were three students who submitted no time logs and commenting that they forgot about those forms.

\section{Overview of Course Projects}

\section{Solar Photovoltaic Grid-Tied Energy Laboratory Equipment. A Mobile Solar} Grid-Tied Unit (MSGTU) was used to demonstrate how solar energy can power a house. As part of this course unit, the team constructed the design location for the inverter, DC cutoff, AC cutoff, breaker box, meter, and wiring routes. The team had to find all of the materials and then space it out on the board provided by the professor. Then, everything was wired together and tested. MSGTU is a very appropriate design project for students who are not familiar with the construction of these systems, because they can clearly see the wiring for each component of the system, giving them a practical understanding of residential solar applications. Since the unit is on wheels, instead of being attached to a stationary wall, the unit is perfect for educational purposes. This unit is exactly what one would expect to see in the industry. Its ability to be mobile makes it ideal for training in the workplace and classrooms. The team learned functional electrical wiring and how to construct a functional model in a safe manner. The project gave the students practical and relatable knowledge on how solar energy can be used. Figures 1a and Figure $1 \mathrm{~b}$ shows the photos of the unit built and how the team tested the unit outside.

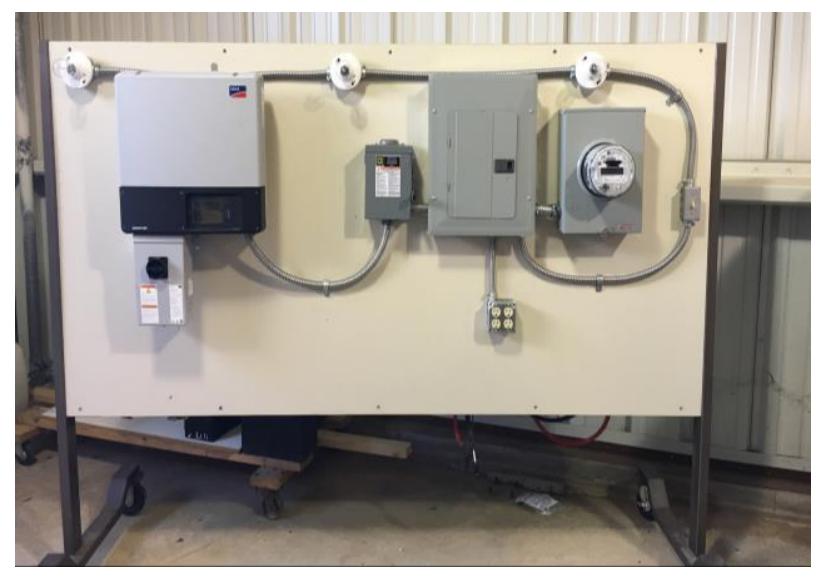

a) Mobile Solar Grid-Tie Unit

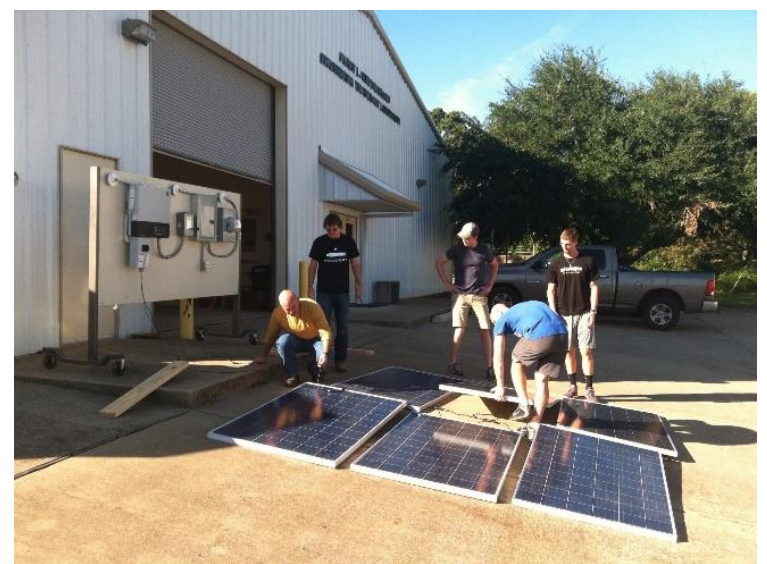

b) Student Team Testing the System

Figure 1. Grid-Tied Solar Photovoltaic Unit and Testing Process

2. Wind-Energy Training Unit Optimization. For the experimental engineering project, the team decided to work at the wind energy modular trainer provided by De Lorenzo Engineering Training Solutions. The primary objectives were to learn as much as the students could about the components of a wind- energy training unit as well as wind energy in general and then apply that knowledge to assembling and operating various configurations of the wind unit. In order to accomplish these objectives, the team got in contact with the De Lorenzo support team and engineers. They successfully answered all of the students' questions and provided them with a manual and the latest software for the unit. By the end of this project, the team was successful in configuring the wind-energy training unit so that it could properly charge 
a battery, output AC and DC for a powered light, and emulate each operation mode of a commercial Microwind turbine. The wind-energy modular training unit is a system that safely converts kinetic to electrical energy using the rotational motion from a wind turbine in a controlled environment. For indoor use, a 24-volt DC motor was used to simulate the wind effect on the shaft of a generator of a traditional wind turbine.

By the end of this project, the team was able to reconstruct and demonstrate all of the possible configurations of the wind unit. Additionally, they acquired further insight about the circuitry and components of the wind unit through De Lorenzo support. The one goal the students did not manage to achieve was outputting the wind unit's electrical data to the De Lorenzo computer software. Throughout this project, the wind energy modular trainer taught the team a great deal about the practical applications of wind energy. The project also furthered their troubleshooting abilities and group coordination. Figure 2 shows the unit under test by the team members.

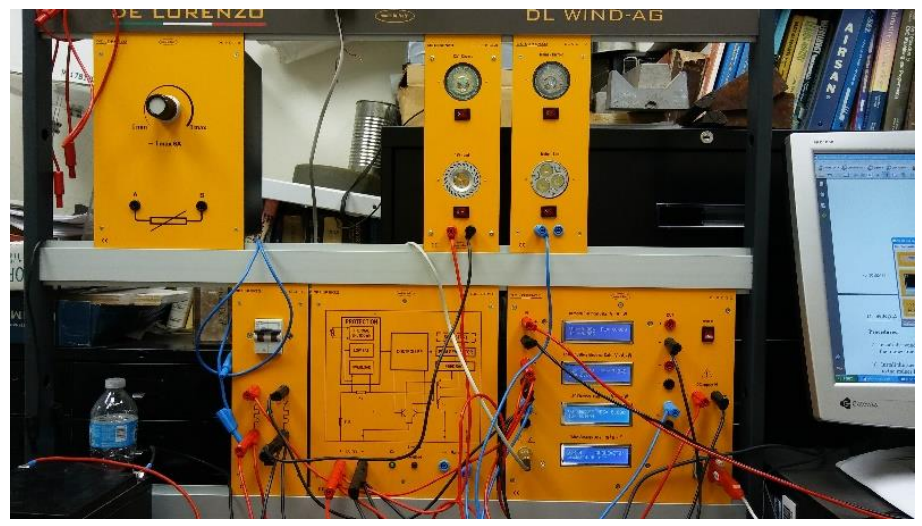

Figure 2. Wind Trainer Unit under Test

3. Electric Car Technology. This project focused on attempting to achieve zero emissions from a vehicle. The vehicle was received as a donation and was not a functioning vehicle. The car sat idle until the Fall 2016 semester, when the team was assigned to refurbish the vehicle in an experimental engineering projects class. The car came with a manual for converting electric cars, Convert It, by Michael P. Brown, with Shari Prange. This manual provided schematics and details that were found to be useful during the refurbishment of the car. There was also a binder full of wiring and vacuum schematics that was used, as well. First, the team diagnosed the car by measuring the voltage in the batteries; they used a battery tester that was purchased from Harbor Freight and found that the batteries had no charge or voltage and were beyond repair. The teaching assistant took the dead batteries to Interstate Batteries and exchanged them for refurbished deep cycle marine batteries at \$35 each. The team tested the new batteries, and found that they were acceptable. After installing the new propulsion batteries into the car, the team drove the car around the parking lot to test the propulsion system. They noticed the charger in the car was the cause of the damage to the old batteries, so pulled out. After assessing the damaged charger, the team discussed many different charging alternatives for the electric car and decided to use a trickle-cell charger to keep the batteries charged. The team built a charging station with six trickle-cell chargers in the front and six in the back that were each connected to an individual battery. All the chargers connected at a power strip where they received energy. This charging setup allowed each individual battery to have its own personal 
smart charger. This ensures that the batteries will not be overcharged and damaged. Next, the team evaluated the status of the car for state inspection so that it would be street legal. After they found that the brakes and tail lights needed to be replaced, and the headlights were not working, the bulbs on the rear lights were replaced and the wiring to the front headlights was altered to bring them up to par. The team then took the car to get inspected and insured.

In conclusion, the students received the car in non-working condition, but after their work, the car is now operable and is street legal. The team diagnosed that the batteries had failed because of the poorly designed charging system. The failed batteries were replaced, and the team redesigned the charging system to be a parallel setup. From this experiment, the students learned how deep cycle marine batteries react to discharge and recharge while in a series connection. They also learned how to properly charge these batteries while connected in series without damaging them. Figure 3 a shows the wiring diagram of the charging station. Figure $3 \mathrm{~b}$ shows the tester used by the students to test battery life [10]. Figure 3c shows the trickle charger purchased to implement the parallel charger design station [11]. Figure $3 \mathrm{~d}$ shows the electric vehicle.
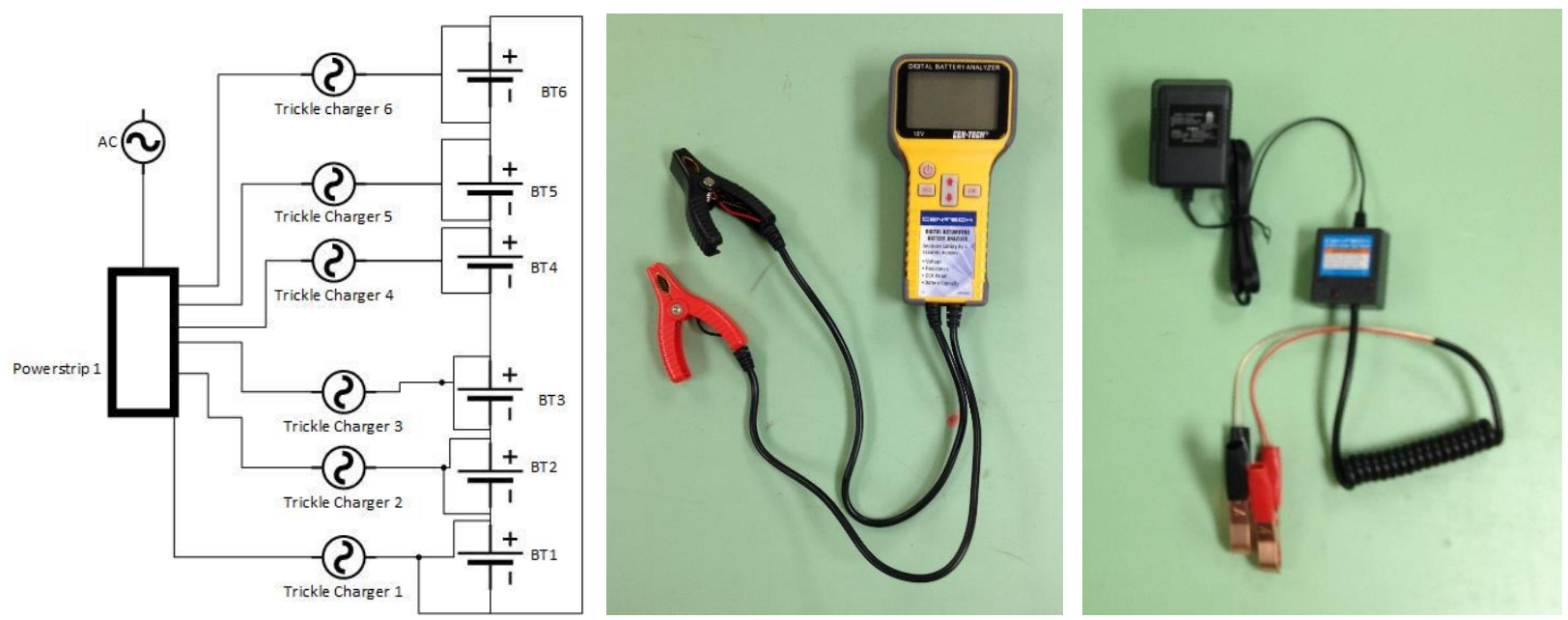

Figure 3a. Charger Schematic

Figure 3b. Battery Tester/analyzer Figure 3c. Trickle Charger

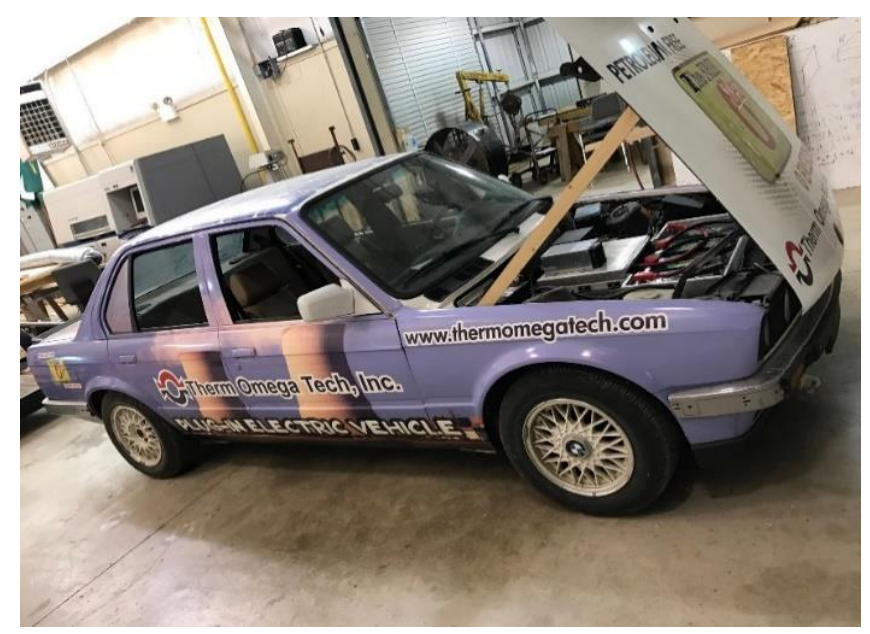

Figure 3d. Electric Vehicle 
4. Energy Generating Bicycle. The team was presented with the challenge of using a stationary bicycle to charge and power a circuit. The many challenges they faced included assembling and designing the structure of the bike, stripping the bike of all conflicting materials, brainstorming different circuits and structures for required components, building a bracket for the alternator used to generate the voltage output, designing and building a circuit using a bread board or soldering, and constructing a display that shows the electronic measurements of the bike's output. The team developed a way to convert the bicycle into an electricity producing bicycle. The next step for the group was to improve on its previous design. The bike currently had a fairly raw frame with a Windstream ${ }^{\circledR}$ Permanent Magnet DC Generator attached by the bottom of the wheel with a small pulley system to generate electricity (Figure 4a, b, c). The goal of the team was to take the output of the bicycle and make a monitor that displays the following electronic measurements: current, voltage, rpm, and power. The monitor was made by two of the group members by using pre-configured meters, or by using a screen powered by Arduino; several of the group members were already familiar with or became familiar with the Arduino board and software.

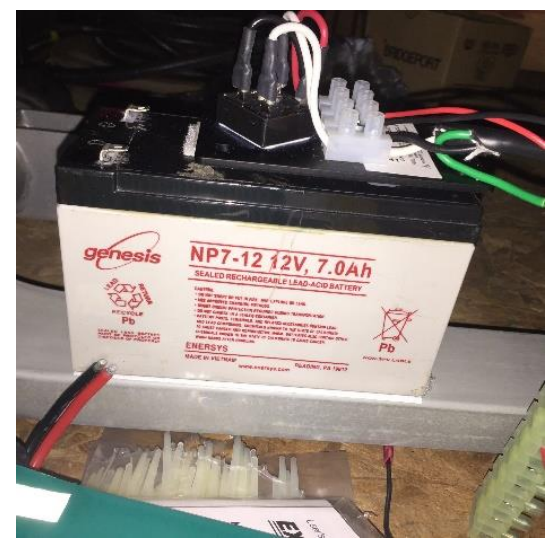

a) Battery with a Rectifier Circuit

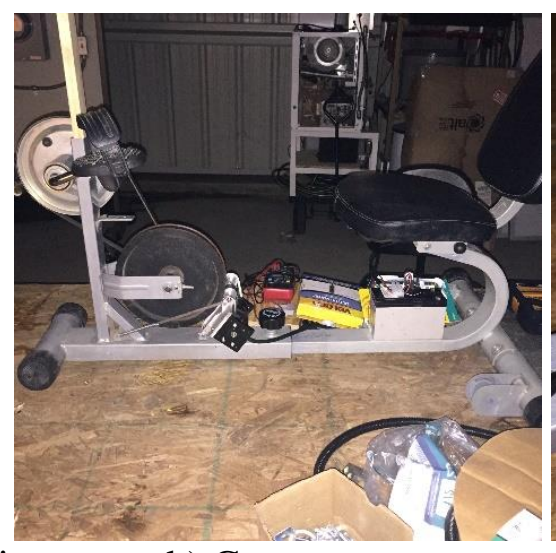

b) Generator

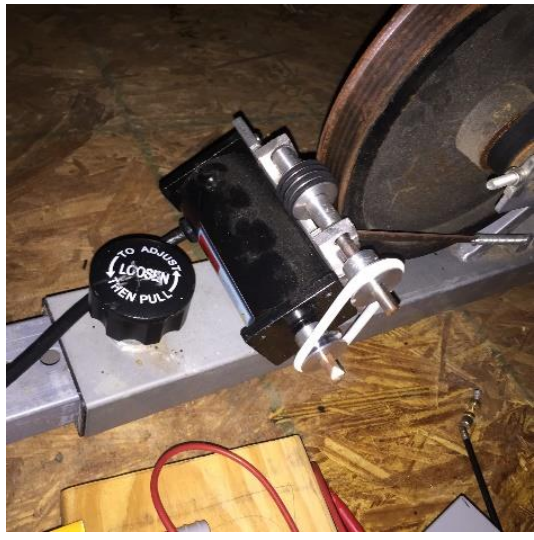

c) Test Bed

Figure 4. Energy Generating Bicycle

The biggest issue of this project was building a circuit that could handle the output of the DC generator. The first solution was to find a meter that could take the high output of 200 volts (open circuit), but a search for these parts soon led the team to realize that there were none available from local stores where they shopped. This issue could not be ignored, because that amount of unregulated voltage hooked up to the monitor would destroy it, and even when the team added the battery as a load, that amount of voltage, if used continuously or for long periods of time, would fry or seriously degrade the performance of the battery. Several different circuit designs were considered and ideas were discussed by the team and course instructor, but more issues arose. The students knew they had to build a circuit that could regulate this energy, but finding parts that could take that kind of voltage were scarce. Second, even if they did accomplish building it, the circuit would be highly inefficient and would release a large amount of heat. Third, the parts needed were too expensive for the team's budget.

At this point, the team knew they had to brainstorm new ideas because the current plan was simply not going to work. This led to eliminating the current DC generator altogether and using 
an alternator. The students chose an alternator because it has a built-in regulator, thus removing the need to build that into our circuit. However, to be able to mount the alternator, they had to build a bracket for it that fit onto the stationary bicycle. The bicycle's length is adjustable, and they did not want to restrict this feature, so to make the bracket work without restricting the bicycle's adjustable parts, the team built an aluminum cast to hold the alternator in place (Figure $5 a, b)$.

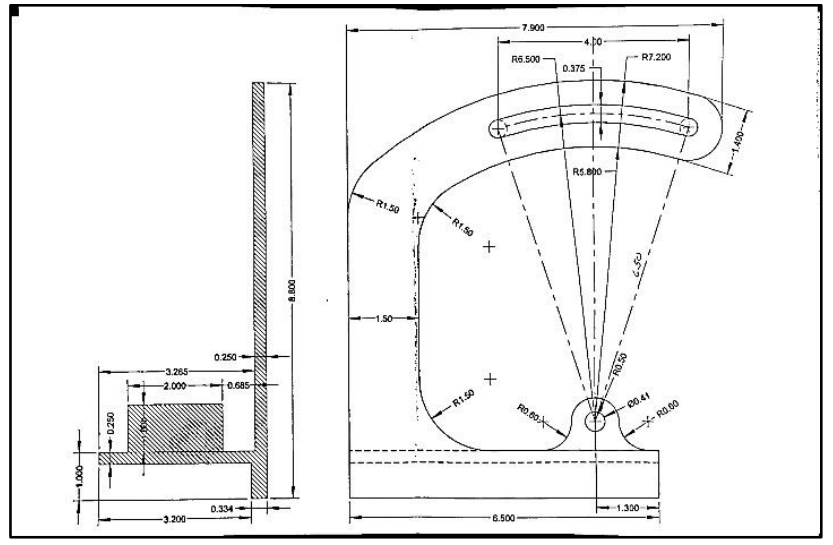

a) Bracket Drawing

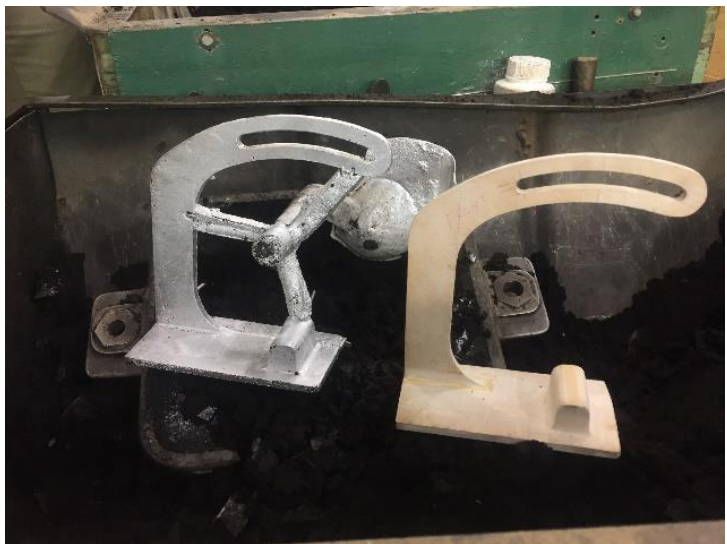

b) Aluminum Casting and Wood pattern

Figure 5. Bracket schematic and the wooden model of cast alongside the aluminum cast

After the bracket was grinded down and sanded, a team member drilled a hole in the base for one of the alternators mounting points. Unfortunately, the hole placement was miscalculated, and the miss-drill destroyed all use of the bracket. Either a new bracket had to be constructed or a new way of mounting the alternator created. One idea was to not use the bicycle at all and create a structure that would not require special aluminum casts to mount all the necessary parts. This alternate structure could also be hand powered to reduce the amount of voltage produced compared to being leg powered. Unfortunately, by this time, the semester was over, and the team was not be able to implement any of these new ideas.

However, on the circuit side of the project, there is now have a fully built DC voltage regulator (Figure 6a, b, c) circuit board, which will be tested by another team as part of their project. Since the students were approaching the end of the semester, they did not have much time left to work on their project. To get all they could out of the project, one of the group members and course instructor spent extra time out of class in the electronics lab to work on it. Despite trying for two hours straight however, they were unable to get the equipment working properly to test everything on the board. The voltage reduction seemed to be operating successfully, however the frequency could not be measured, and without knowing if it was oscillating correctly, the course instructor did not want to put it under a heavy load in fear of damaging the circuit board.

This appeared from the onset to be a somewhat easy project, but it very quickly became one of the most challenging projects of the class. Regardless of how much of the original goals were fulfilled, this bicycle project taught its group members many different concepts and alternate subjects:

- The Arduino board and its software was studied and researched; 
- A light and switch circuit was correctly hooked up to the bike and tested by the team;

- Measurement tools such as multimeters were used frequently;

- In-depth discussions on how to regulate voltage were studied;

- The entire process of making a metal cast was taught and filmed;

- Team members witnessed or used heavy machinery such as saws, drills, and grinders, and learned how soldering is done and surface mounted components are made.

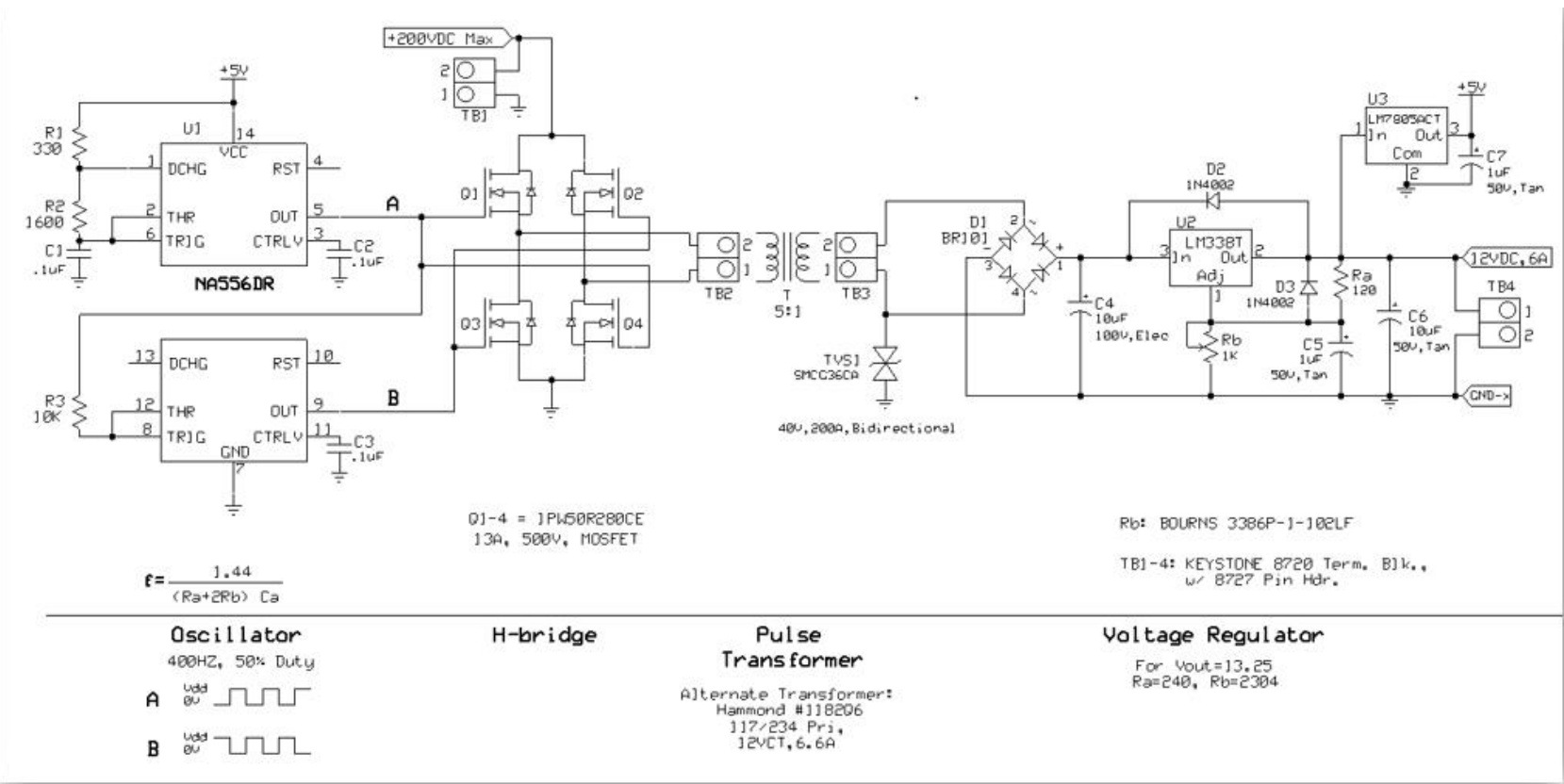

a) Schematic for the DC Voltage Regulator

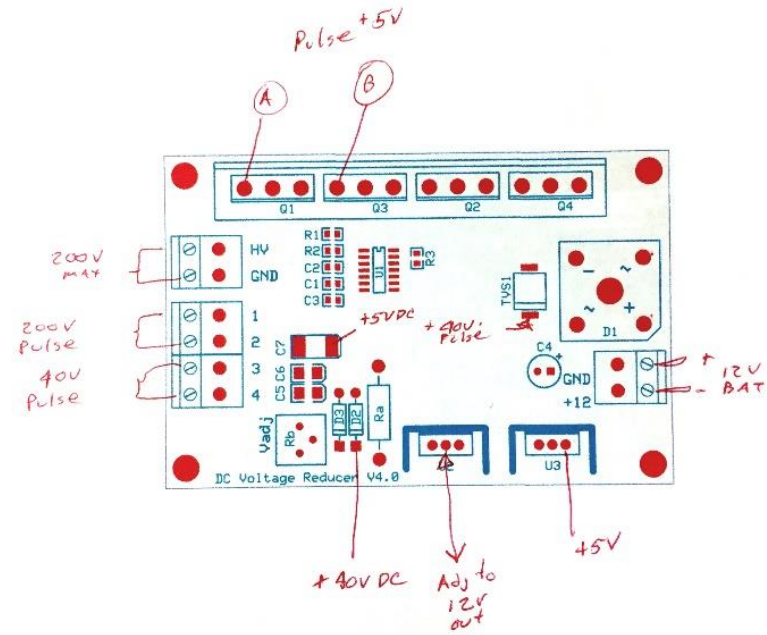

b) Testing Points on the DC Voltage Regulator

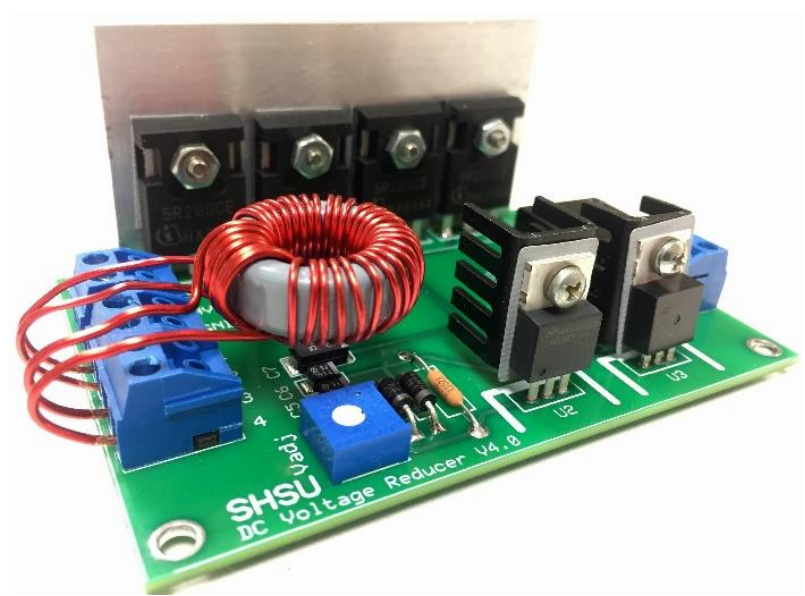

c) DC Voltage Regulator Circuit board

Figure 6. Student Built DC Voltage Regulator

The bicycle project had many issues that the team might not have been fully qualified to handle, but it was a tremendous learning experience for all of them. Unfortunately, because of time constraints, the bicycle project was put on hold until another group could take it over. 
5. Energy-Efficient Construction Materials and Instrumentation Study. The purpose of this study of energy-efficient construction materials and instrumentation was to build a system of sensors and install them in a portable small-scale building. The building would be selfpowered to test and monitor temperature variations through different construction materials. The challenge associated with this project was that there was no inexpensive system to monitor the many sensors required. There are systems on the market that will take care of this, but these systems can cost thousands of dollars and come with few features.

The construction side of the project started with a skeleton of the building. One side of the wall has a brick veneer, one has HardiePlank ${ }^{\circledR}$ siding, and the third has smart siding. The roof of the building was built with conventional roofing and drywall. The team started out building corner boards for each side of the building and then painted the boards to match the already painted sides of the wall. The last step was to install the insulation inside the building. The students used R-13 fiberglass in the walls and R-19 fiberglass for the ceiling. For the electronic side of the project, they used 20 temperature sensors, an Arduino board, an Adafruit data logger board, and two specially designed multiplexer boards. The team started with a partially put together multiplexer shield and then made sure that there were no shorts in the system. The next step was to install the jacks onto the phone lines the students are using. They then soldered the sensors to the phone lines and insulated all the sensors to keep them from shorting. After that, the team tested the sensors to make sure they were working. Figures $7 \mathrm{a}, 7 \mathrm{~b}$, and $7 \mathrm{c}$ shows the sensors with the soldered cords and instrumentation circuit board.
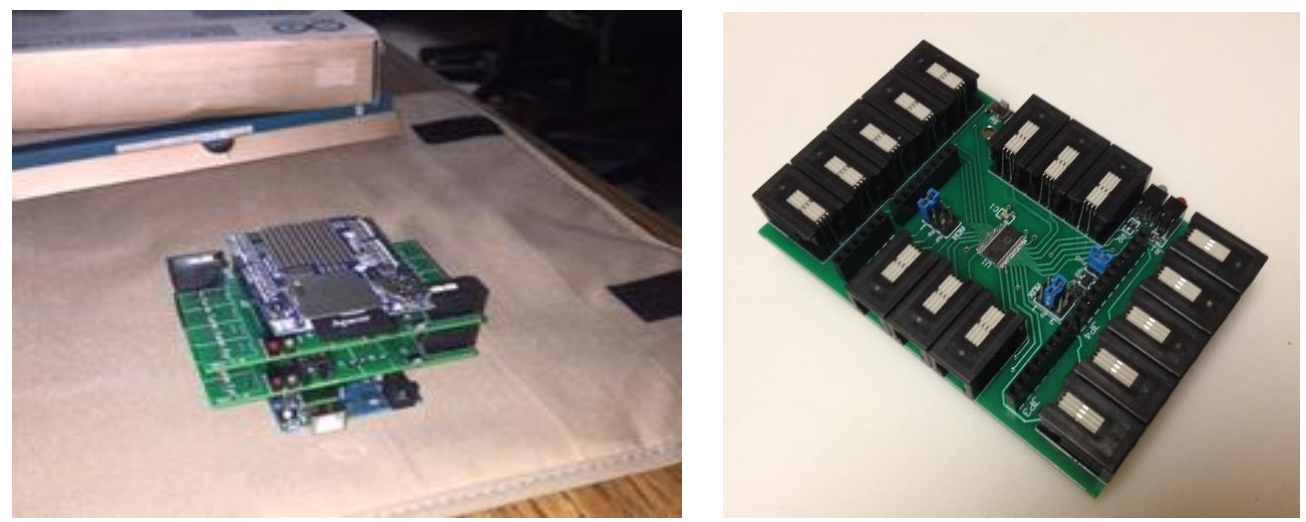

a) Circuit boards

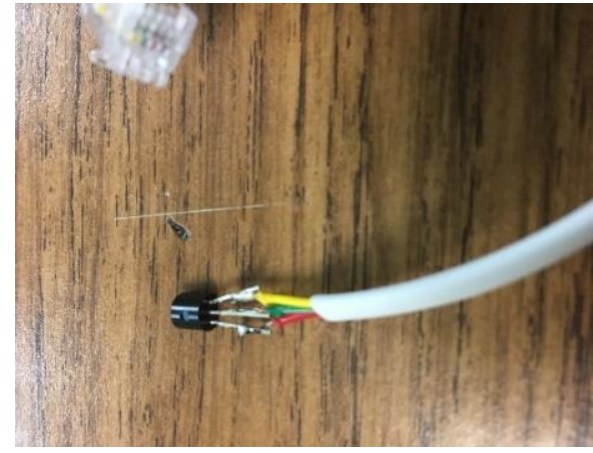

b) Sensor with cord

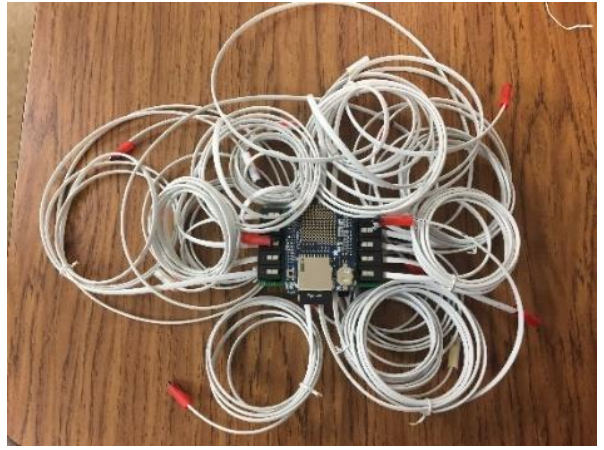

c) Sensors connected to the board

Figure 7. Temperature Instrumentation System 
Since the building can be relocated to different climates and environments, this system would allow construction workers to find not only the least expensive but also the most efficient materials for the construction at a given location. This can benefit architects since it will allow them to know the best likely materials to use in building; it also benefits the owner of the building in terms of knowledge about energy efficiency and initial construction costs. People in research could use this system to discover new and more efficient materials and to test previously unused materials that were thought to be inefficient. To expand the application of this project, more building materials are needed to expand the sample size; thus, a larger structure is needed, but the portability should be maintained. A small movable building on a trailer would be the most efficient way to further this. While expanding the building would be easy, expanding the sensor system would be more difficult. Figure 8 shows the prototype building for the temperature instrumentaion.
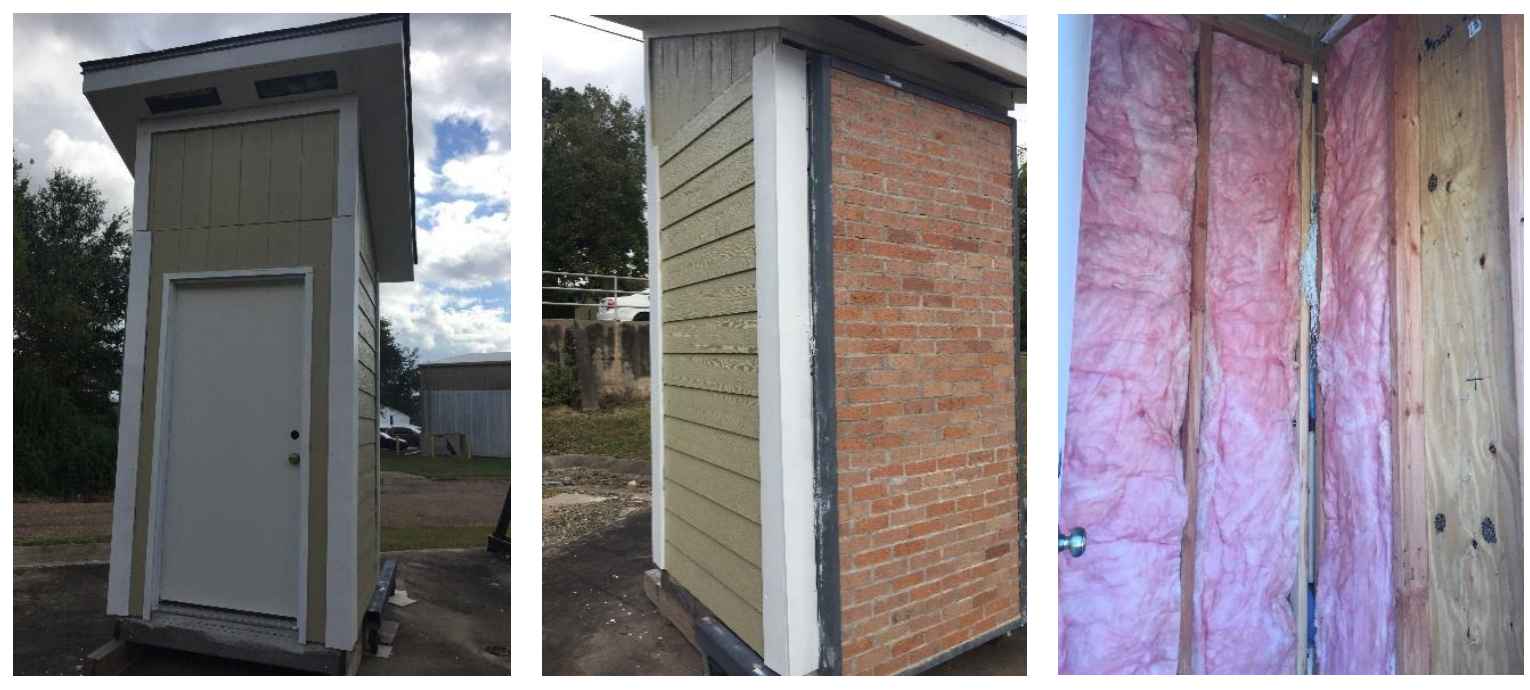

Figure 8. Prototype Building

This design has the benefits of being highly mobile and also needs only simple installation. The boards that operate the system require so little power that they can be run from battery power if a conventional power supply is not available. This is highly effective since some locations for the test building may be chosen prior to construction, and these locations may not have power systems available. While the programming for some of the more expensive systems may be simpler, the overall cost is a drawback. Using a system like this also gives increased mobility so that a variety of different sites and environments can be sampled for their varying effects on the building and its materials.

6. The Solar-Powered Go-Kart. The solar-powered go-kart was designed to travel without gas. The solar panels attached to the back of the car are a renewable energy source. In theory, the car would have a steady amount of energy by a conversion of solar to electrical energy. The materials were tweaked to ensure the car would work to its proper theorized expectations. There were extra parts added such as batteries, rotary devices, and programming tools that would allow the car to be responsive to different programming tools. The car was commercially built. It was ordered online along with its parts to ensure it would be functional. It was designed to be responsive to computer programming and have sunlight as a renewable 
recharge energy resource. Its advertised purpose was to entertain children ages 8 to 15 , for at least 30 minutes to an hour and was made to travel up to 40 miles per hour.

Two batteries were attached to the car to get at least 30 minutes of battery life. The travel time was determined in a theoretical equation pertaining to the amount of load in equivalency to the battery life and rotary devices. (The amount of load was also configured into the travel time of the car). The working factors of the vehicle were determined based on the weight of all the equipment, the child in the vehicle, and the solar panel attached to the back of the vehicle. The car itself was a small go-kart type vehicle.

The go-kart ran smoothly from the time it was tested. All parts functioned well once they were purchased. The main problem with using a go-kart for a project would be the initial purchase and length of time required for it to arrive since these are items are only available through the internet. The panel was built to be the renewable energy source for the go-kart. Along with an energy regulator, the solar panel was used to back-up the battery as a sort of constant refueling station. While building the panel, it became increasingly difficult to attach the cells in a correct manner to get a good amount of voltage. The cells were flimsy and easily broken if accidentally hit; this was a huge challenge for the team members when they soldering the cells together. Also, the purchased cells required soldering on both front and back. This made it more difficult to attach them together.

This project was a great learning experience, for although it was very time consuming, it was educational. The first idea for the panel was for it to run off a hydrogen fuel cell, but due to the complexity of the fuel cell system, that particular renewable energy source was substituted with solar power, which is much safer. In conclusion, this experiment was a very exciting and challenging one. This was a lengthy project and it was done to the best of the ability of the students designing it. It was a lot of fun and testing it was a lot of fun to watch. It was a great success, for the panel exported the necessary amounts of energy, and the car was driven from campus to the production lab with few alterations. The alterations were caused by problems in the wiring which were fixed. Figure 9 shows project photos of the go-kart, and a student soldering the solar cells.
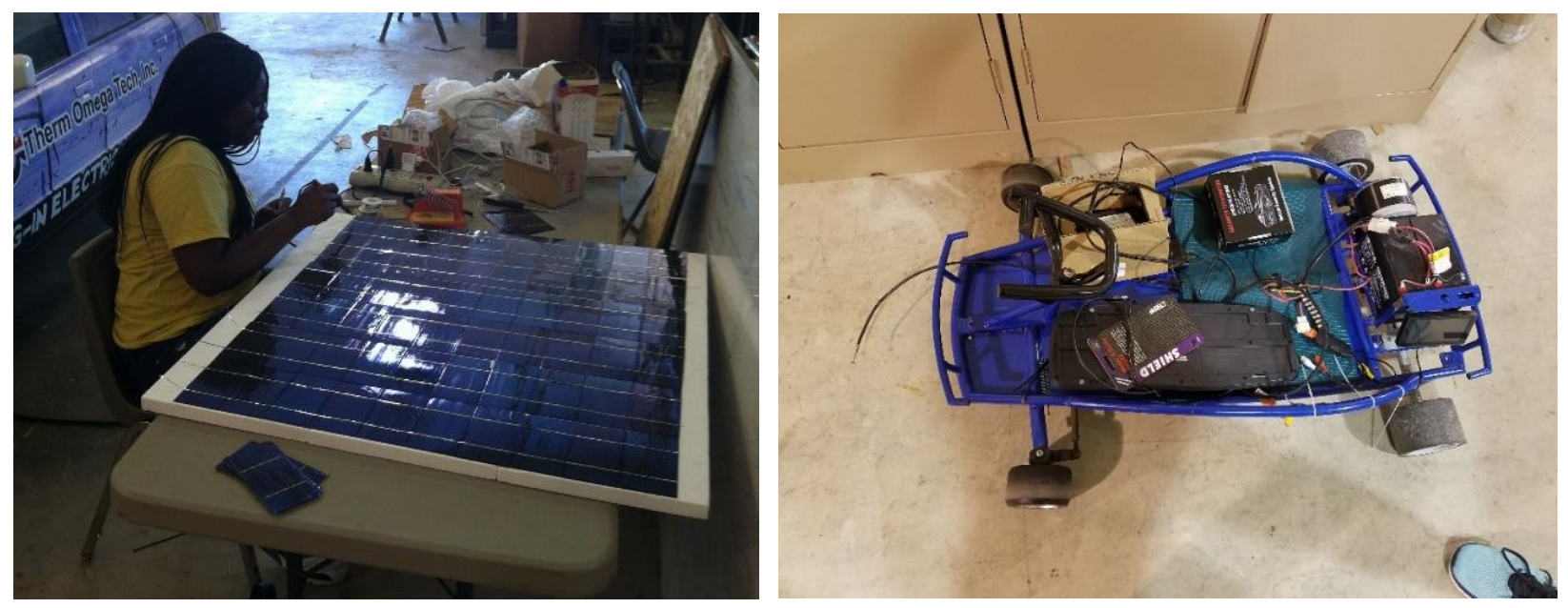

Figure 9. Go-Cart and Photovoltaic Solar Cell Soldering 
7. Bracket Design for a Two-Different-Sized Inverter Installation. One team's project was to add an electronic inverter to an existing electronic experimentation board. The students were to add a second bigger and more powerful electronic inverter to an already cramped electronic board. This task was difficult because of the limited space they had to work with, and because they had to stack the two inverters on top of one another to use the space effectively and efficiently.

For this project, the team did not have an instruction manual for guidance. They knew after being shown the electronic board that it was going to be challenging to effectively mount a second inverter while taking up minimal space. Adding the second inverter would prove to be difficult, but with the professional guidance the students were able to seek out, they knew the task was possible. They started this experiment by contemplating how to best use the allotted space they had to work with. The team sought out the advice of the instructor and teaching assistant available and after explaining the method they desired to use, the team got approval and started to order the materials necessary to complete the project. In order to accomplish the goal of implementing a second inverter, the students decided to use aluminum pieces of metal to go on either side of the existing inverter. These aluminum pieces would allow the team to mount a second inverter on the top of the already existing inverter. By placing eight inches of aluminum to serve as a mounting surface, they would be able to accomplish our goal.

The first step was to order the aluminum metal material and purchase screws, washers, and nuts. When the team received the materials, the next step was to take measurements of the current already existing inverter and find out the correct length of the aluminum mounting pieces they would be working with. Once the measurements were taken, the team members cut the aluminum in appropriate sizes. Once the first piece of metal was cut, that piece could be used as a template for making the remaining pieces, since there needed to be enough pieces to fix four different electronic boards. After the metal was cut, holes drilled, and extra metal shaved, the team mounted the necessary components by using, screws to first mount the aluminum pieces to the board with the first inverter. In order to do this, the screws had to come from the bottom of the board and include a washer and a nut to secure the hold. Once the students finished mounting the aluminum brackets, they set the new inverter on top and used pre-drilled holes to secure the second inverter. Once the top inverter was mounted, the team accomplished their goal on the first electronic board and then repeated the steps for the remaining three boards. Figures 10a and 10b show the bracket drawing and the installed inverters.

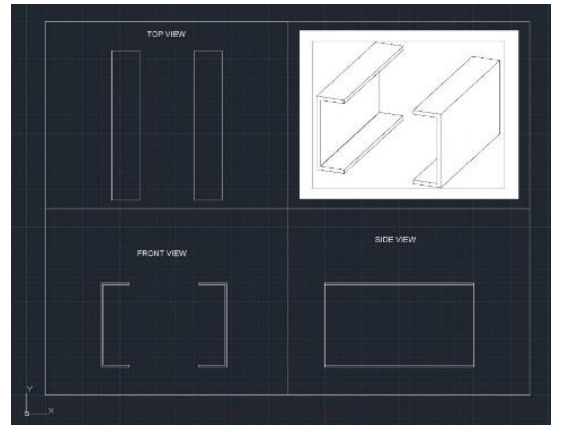

a) Bracket Drawing

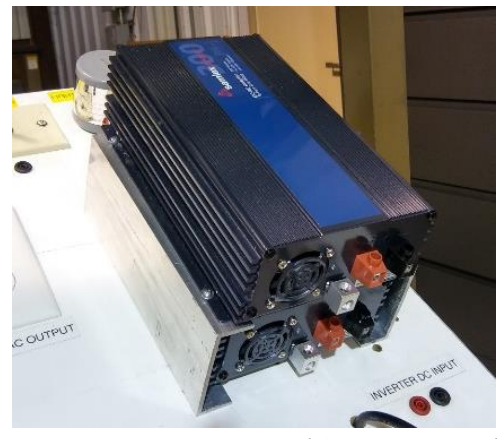

b) Mounted Inverters

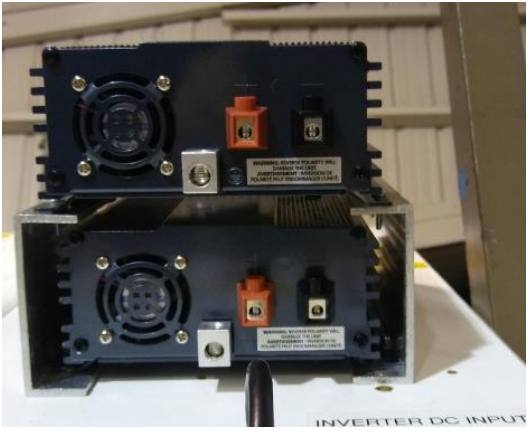

Figure 10. Bracket Drawing and Installed Inverters 
By taking necessary precautions and using all the materials and advice available to the teams, they were able to accomplish their goal of installing a second inverter for all four electronic boards. Without the guidance and teamwork the students displayed the project would have not been possible.

\section{Grading and Assessments}

Students and teams were assessed based on their group's project presentation, project poster, project paper, the extra time students spent in the laboratory environment (recorded on their time $\operatorname{logs}$ ), and their performance throughout the semester.

Each group gave a 20-minute presentation to the class, with 5 minutes of the total time allocated for questions. A rubric was provided to the students so they would be aware of the criteria used for assessment; the assessments were done by each student and also by the instructor in the class, who collected and tallied the scores from all the rubrics students filled. The scoring rubric is provided in Appendix B.

Each project team prepared a poster after formatting and content details were provided to the students. Project posters were graded by the course instructor for the initial semester, however, it is suggested that a scoring rubric be prepared for the students to evaluate the project posters the next time the class is taught. Students presented their projects with the posters at a departmental building dedication event where the President of the University, Academic Deans, alumni of the department, faculty, and staff were present. Students were also encouraged to present their posters at the annual research symposium organized by the University in April 2017.

Students were also asked to write a project paper as a team, and the paper were evaluated based on academic publication guidelines. Students included an abstract, introduction, literature review, body of the work, figures, graphs, captions, tables, part lists, all the references/citations, appendix, etc. These papers were graded by the instructor.

Students were not provided an official survey to assess this project based course. However, students filled out online course assessment forms (IDEA) to evaluate the course and the course instructor as required by the university. Out of 19 students, 17 students responded to the course evaluation questions (89.47\%). The quantitative results are summarized in Table 4.

Table 4 summarizes quantitative assessment based on 3 main titles, a) describe your progress on, b) the course (compare this course with others you have taken at this institution, c) course, instructor, and student progress. 
Table 4. Quantitative Course Assessments

\begin{tabular}{|c|c|c|c|c|c|c|c|c|c|}
\hline \multicolumn{10}{|c|}{ Describe your progress on: } \\
\hline $\begin{array}{c}\text { No Apparent } \\
\text { Progress }\end{array}$ & $\begin{array}{c}\text { Slight } \\
\text { Progress }\end{array}$ & \multicolumn{2}{|c|}{$\begin{array}{l}\text { Moderate } \\
\text { Progress }\end{array}$} & $\begin{array}{c}\text { Substantial } \\
\text { Progress }\end{array}$ & $\begin{array}{c}\text { Exceptional } \\
\text { Progress }\end{array}$ & $\begin{array}{c}\text { Mean } \\
\text { M }\end{array}$ & $\begin{array}{c}\text { Standard } \\
\text { Deviation } \\
\text { SD }\end{array}$ & $\begin{array}{c}\text { Did Not } \\
\text { Answer } \\
\text { DNA }\end{array}$ & $\begin{array}{c}\text { Total } \\
\text { Responses } \\
\mathbf{N}\end{array}$ \\
\hline \multicolumn{10}{|c|}{ Gaining a basic understanding of the subject (e.g., factual knowledge, methods, principles, generalizations, theories) } \\
\hline $\begin{array}{l}0 \% \\
0\end{array}$ & $\begin{array}{l}0 \% \\
0\end{array}$ & \multicolumn{2}{|c|}{$5.88 \%$} & $\begin{array}{l}41.18 \% \\
7\end{array}$ & \begin{tabular}{|l|l|}
$52.94 \%$ \\
9
\end{tabular} & 4.47 & 0.61 & \multirow[t]{2}{*}{0} & 17 \\
\hline \multicolumn{9}{|c|}{ Developing knowledge and understanding of diverse perspectives, global awareness, or other cultures } & \\
\hline $\begin{array}{l}5.88 \% \\
1\end{array}$ & $0 \%$ & \multicolumn{2}{|c|}{\begin{tabular}{|l|l|}
$5.88 \%$ \\
1
\end{tabular}} & $\begin{array}{l}35.29 \% \\
6\end{array}$ & $\begin{array}{l}52.94 \% \\
9\end{array}$ & \multirow[t]{2}{*}{4.29} & \multirow[t]{2}{*}{1.02} & 0 & 17 \\
\hline \multicolumn{8}{|c|}{ Learning to apply course material (to improve thinking, problem solving, and decisions) } & & \\
\hline $\begin{array}{l}0 \% \\
0\end{array}$ & $\begin{array}{l}5.88 \% \\
1\end{array}$ & \multicolumn{2}{|c|}{2} & $\begin{array}{l}23.53 \% \\
4\end{array}$ & $\begin{array}{l}58.82 \% \\
10\end{array}$ & 4.35 & 0.9 & 0 & 17 \\
\hline Developing specific & c skills, competenci & es, and $\mathrm{p}$ & oints of view ne & needed by professionals & in the field most closely rel & ated to this cours & & & \\
\hline $\begin{array}{l}0 \% \\
0\end{array}$ & $\mid \begin{array}{l}0 \% \\
0\end{array}$ & $0 \%$ & & $\begin{array}{l}29.41 \% \\
5\end{array}$ & $\begin{array}{l}70.59 \% \\
12\end{array}$ & 4.71 & 0.46 & 0 & 17 \\
\hline Acquiring skills in & working with other & $\frac{1}{\mathrm{~s} \text { as a mer }}$ & mber of a team & & & & & & \\
\hline $\begin{array}{l}0 \% \\
0\end{array}$ & \begin{tabular}{l|l}
$0 \%$ \\
0
\end{tabular} & $\begin{array}{l}5.88 \% \\
1\end{array}$ & & $\begin{array}{l}23.53 \% \\
4\end{array}$ & $\begin{array}{l}70.59 \% \\
12\end{array}$ & 4.65 & 0.59 & 0 & 17 \\
\hline Developing creative & e capacities (inventi & ng; desig & gning; writing; & performing in art, music & c, drama, etc.) & & & & \\
\hline $\begin{array}{l}11.76 \% \\
2\end{array}$ & $\begin{array}{l}5.88 \% \\
1\end{array}$ & 11.76 & & \begin{tabular}{|l|l}
$23.53 \%$ \\
4
\end{tabular} & $\begin{array}{l}47.06 \% \\
8\end{array}$ & 3.88 & 1.37 & 0 & 17 \\
\hline Gaining a broader $\mathrm{u}$ & understanding and $\mathrm{a}$ & ppreciatic & ion of intellectu & ual/cultural activity (mus & sic, science, literature, etc.) & & & & \\
\hline $\begin{array}{l}5.88 \% \\
1\end{array}$ & $\begin{array}{l}5.88 \% \\
1\end{array}$ & $\begin{array}{l}17.65 \\
3\end{array}$ & & $\begin{array}{l}17.65 \% \\
3\end{array}$ & $52.94 \%$ & 4.06 & 1.21 & 0 & 17 \\
\hline Developing skill in & expressing myself & orally or $\mathrm{i}$ & in writing & & & & & & \\
\hline $\begin{array}{l}5.88 \% \\
1\end{array}$ & $\begin{array}{l}5.88 \% \\
1\end{array}$ & $\begin{array}{l}17.65 \\
3\end{array}$ & & $\begin{array}{l}5.88 \% \\
1\end{array}$ & $\begin{array}{l}64.71 \% \\
11\end{array}$ & 4.18 & 1.25 & 0 & 17 \\
\hline Learning how to fin & d, evaluate, and use & e resource & es to explore a & topic in depth & & & & & \\
\hline $\begin{array}{l}0 \% \\
0\end{array}$ & $\begin{array}{l}5.88 \% \\
1\end{array}$ & $\begin{array}{l}11.76 \\
2\end{array}$ & & $\begin{array}{l}17.65 \% \\
3\end{array}$ & $\begin{array}{l}64.71 \% \\
11\end{array}$ & 4.41 & 0.91 & 0 & 17 \\
\hline Developing ethical & reasoning and/or et & hical deci & ision making & & & & & & \\
\hline $\begin{array}{l}11.76 \% \\
2\end{array}$ & $\begin{array}{l}5.88 \% \\
1\end{array}$ & $\begin{array}{l}5.88 \% \\
1\end{array}$ & & $\begin{array}{l}17.65 \% \\
3\end{array}$ & $\begin{array}{l}58.82 \% \\
10\end{array}$ & 4.06 & 1.39 & 0 & 17 \\
\hline Learning to analyze & and critically evalu & uate ideas & s, arguments, at & and points of view & & & & & \\
\hline $\begin{array}{l}11.76 \% \\
2\end{array}$ & $0 \%$ & $\begin{array}{l}5.88 \% \\
1\end{array}$ & $\%$ & \begin{tabular}{|l|}
$23.53 \%$ \\
4
\end{tabular} & $\begin{array}{l}58.82 \% \\
10\end{array}$ & 4.18 & 1.29 & 0 & 17 \\
\hline Learning to apply $\mathrm{k}$ & nowledge and skills & to benef & fit others or ser & rve the public good & & & & & \\
\hline $\begin{array}{l}0 \% \\
0\end{array}$ & $\begin{array}{l}11.76 \% \\
2\end{array}$ & $\begin{array}{l}11.76 \\
2\end{array}$ & & $\begin{array}{l}23.53 \% \\
4\end{array}$ & $\begin{array}{l}52.94 \% \\
9\end{array}$ & 4.18 & 1.04 & 0 & 17 \\
\hline Learning appropria & te methods for colle & $\frac{1}{\text { cting, an }}$ & $\stackrel{1}{\text { halyzing, and int }}$ & terpreting numerical inf & ormation & & & & \\
\hline $\begin{array}{l}5.88 \% \\
1\end{array}$ & $\begin{array}{l}5.88 \% \\
1\end{array}$ & $\begin{array}{l}5.88 \% \\
1\end{array}$ & & $\begin{array}{l}35.29 \% \\
6\end{array}$ & $\begin{array}{l}47.06 \% \\
8\end{array}$ & 4.12 & 1.13 & 0 & 17 \\
\hline $\begin{array}{l}\text { The Course: } \\
\text { On the next two }\end{array}$ & items, compare t & cours & se with others & s you have taken at & his institution. & & & & \\
\hline $\begin{array}{l}\text { Much Less tha } \\
\text { Most Courses }\end{array}$ & $\begin{array}{l}\text { Less than } \\
\text { Cours }\end{array}$ & $\begin{array}{l}\text { Most } \\
\text { es }\end{array}$ & $\begin{array}{c}\text { About } \\
\text { Average }\end{array}$ & $\begin{array}{c}\text { More than Most } \\
\text { Courses }\end{array}$ & $\begin{array}{l}\text { Much More than } \\
\text { Most Courses }\end{array}$ & $\begin{array}{c}\text { Mean } \\
\text { M }\end{array}$ & $\begin{array}{c}\text { Standard } \\
\text { Deviation } \\
\text { SD }\end{array}$ & $\begin{array}{c}\text { Did Not } \\
\text { Answer } \\
\text { DNA }\end{array}$ & $\begin{array}{c}\text { Total } \\
\text { Responses } \\
\text { N }\end{array}$ \\
\hline Amount of coursew & vork & & & & & & & & \\
\hline $\begin{array}{l}5.88 \% \\
1\end{array}$ & $\begin{array}{l}11.76 \% \\
2\end{array}$ & & $\begin{array}{l}41.18 \% \\
7\end{array}$ & $\begin{array}{l}23.53 \% \\
4\end{array}$ & $\begin{array}{l}17.65 \% \\
3\end{array}$ & 3.35 & 1.08 & 0 & 17 \\
\hline Difficulty of subjec & $\frac{1}{1}$ & & & & & & & & \\
\hline $\begin{array}{l}0 \% \\
0\end{array}$ & \begin{tabular}{|l|l|} 
& $5.88 \%$ \\
& 1
\end{tabular} & & $\begin{array}{l}47.06 \% \\
8\end{array}$ & $\begin{array}{l}23.53 \% \\
4\end{array}$ & $\begin{array}{l}23.53 \% \\
4\end{array}$ & 3.65 & 0.9 & 0 & 17 \\
\hline For the following & items, choose th & e option & that best cor & rresponds to your jud & Igment. & & & & \\
\hline $\begin{array}{l}\text { Definitely } \\
\text { False }\end{array}$ & $\begin{array}{c}\text { More False t } \\
\text { True }\end{array}$ & han & $\begin{array}{c}\text { In } \\
\text { Between }\end{array}$ & $\begin{array}{c}\text { More True th } \\
\text { False }\end{array}$ & $\begin{array}{c}\text { Definitely } \\
\text { True }\end{array}$ & $\begin{array}{c}\text { Mean } \\
\text { M }\end{array}$ & $\begin{array}{l}\text { Standard } \\
\text { Deviation } \\
\text { SD } \\
\end{array}$ & $\begin{array}{l}\text { Did Not } \\
\text { Answer } \\
\text { DNA }\end{array}$ & $\begin{array}{c}\text { Total } \\
\text { Responses } \\
\text { N }\end{array}$ \\
\hline As a rule, I put fort & h more effort than o & ther stude & dents on academ & nic work. & & & & & \\
\hline $\begin{array}{l}5.88 \% \\
1\end{array}$ & $\begin{array}{l}0 \% \\
0 \\
\end{array}$ & & $\begin{array}{l}29.41 \% \\
5\end{array}$ & $\begin{array}{l}35.29 \% \\
6\end{array}$ & $\begin{array}{l}29.41 \% \\
5\end{array}$ & 3.82 & 1.04 & 0 & 17 \\
\hline I really wanted to to & ke this course re & dless of $\mathrm{y}$ & who taught it. & & & & & & \\
\hline $\begin{array}{l}0 \% \\
0\end{array}$ & $\begin{array}{l}11.76 \% \\
2\end{array}$ & & $\begin{array}{l}5.88 \% \\
1\end{array}$ & $\begin{array}{l}47.06 \% \\
8\end{array}$ & $\begin{array}{l}35.29 \% \\
6\end{array}$ & 4.06 & 0.94 & 0 & 17 \\
\hline When this course & egan I believed I co & uld maste & er its content. & & & & & & \\
\hline $\begin{array}{l}5.88 \% \\
1\end{array}$ & $\begin{array}{l}0 \% \\
0\end{array}$ & & $\begin{array}{l}17.65 \% \\
3\end{array}$ & $\begin{array}{l}35.29 \% \\
6\end{array}$ & $\begin{array}{l}41.18 \% \\
7\end{array}$ & 4.06 & 1.06 & 0 & 17 \\
\hline My background pre & pared me well for tl & his course & e's requirement & & & & & & \\
\hline $\begin{array}{l}5.88 \% \\
1\end{array}$ & $\begin{array}{l}0 \% \\
0\end{array}$ & & $\begin{array}{l}11.76 \% \\
2\end{array}$ & $\begin{array}{l}29.41 \% \\
5\end{array}$ & $\begin{array}{l}52.94 \% \\
9\end{array}$ & 4.24 & 1.06 & 0 & 17 \\
\hline Overall, I rate this & nstructor an exce & nt teacher & & & & & & & \\
\hline $\begin{array}{l}0 \% \\
0 \\
\end{array}$ & \begin{tabular}{|l|}
$0 \%$ \\
0
\end{tabular} & & $\begin{array}{l}0 \% \\
0\end{array}$ & $\begin{array}{l}41.18 \% \\
7\end{array}$ & $\begin{array}{l}58.82 \% \\
10\end{array}$ & 4.59 & 0.49 & 0 & 17 \\
\hline Overall, I rate this & course as excellent. & & & & & & & & \\
\hline $\begin{array}{l}0 \% \\
0\end{array}$ & $\begin{array}{l}0 \% \\
0\end{array}$ & & $\begin{array}{l}5.88 \% \\
1\end{array}$ & $\begin{array}{l}41.18 \% \\
7\end{array}$ & $\begin{array}{l}52.94 \% \\
9\end{array}$ & 4.47 & 0.61 & 0 & 17 \\
\hline
\end{tabular}




\section{Discussions}

Working with undergraduate students can be a challenge to the course instructor because undergraduate students have less knowledge and have had less preparation for potential interdisciplinary research projects. Most of the students in this course were taking a full load of classes and working in part/full time jobs. The student time commitment to work on the project outside of the class time, especially, was not successful when time logs were tallied and graded by the course instructor. Only two of the students spent a major amount of time (3-4 hrs. per week) in the lab environment to finish the projects. Despite many reminders from the instructor to spend additional time in the lab environments, students could not meet this challenge. Several reasons are: (a) not all team members were available to work together; (b) materials were not ready; (c) the lab was not open or supervised when students were available, etc. These reasons will be considered to improve the class when it is offered again. Another challenge was the availability of the materials, budget allocation, and ordering process of the materials. There was not an allocated budget for potential additional materials for the projects. Therefore, the course instructor spent his travel budget to buy materials for the projects. Students were asked to identify inexpensive component(s) due to budget limitations. The time required for ordering and receiving process of some of the materials needed for the projects was a challenge because this delayed completion of the projects. Furthermore, some of the students had to wait for their team members to finish their parts, in order for others to complete their part the project. Students were always reminded that all the team members should work together at every stage of the project to learn from other disciplines. Based on verbal feedback from the students, they learned from their team members, but the instructor should expect to spend time emphasizing the importance of interdisciplinary projects to prepare them for their future careers. The instructor plans to work on a new scoring rubric for the team members so they can evaluate each other's performance for future classes.

\section{Conclusion}

In industry and in the business world, experts from different disciplines and levels of expertise work together on different projects. This course gives the students experience which will prepare them for real world projects. The teams are responsible for the design, development, maintenance, and manufacturing of several projects. At the end of the semester, each project team is required to submit a final report, a research poster, and give a final presentation. Presentations are assessed by faculty and students in the class on presentation skills, knowledge base, critical thinking, and overall impressions. This paper discussed the need for the course, the projects' details, student information, assessment process, and the results. In addition, the discussions and observations made by the students, along with the difficulties and successes are presented. In an effort to improve the hands-on project experience in the Engineering Technology Program, an engineering experimental project course from six different degrees was implemented. To evaluate and improve integration effort, an assessment and evaluation methods were developed. The effectiveness of the integration can be measured by the evaluations and comments of students as well as by those of the course instructor. Project teams' progress at different stages and in various ways was observed and rated by the course instructor and students. The assessments and comments showed that many of the students believed that their teamwork and hands-on skills improved because of this interdisciplinary concept. 


\section{References}

[1] Probst, D. (2002), A Proposed Interdisciplinary Senior Capstone Course. Proceedings, 2002 Annual ASEE Conference \& Exposition, Montreal, Canada. https://peer.asee.org/10307

[2] Dudevoir, G., \& Laffely, A., \& Mundy, A. J. (2010), Survivor" Meets Senior Project. Proceedings, 2010 Annual Conference \& Exposition, Louisville, Kentucky. https://peer.asee.org/16267

[3] Sirinterlikci, A. (2014), Interdisciplinary Capstone Projects. Proceedings, 2014 ASEE Annual Conference \& Exposition, Indianapolis, Indiana. https://peer.asee.org/20691

[4] King, L., El-Sayed, M., Sanders, M., El-Sayed, J. (2005), Job Readiness through Multidisciplinary Integrated Systems Capstone Courses. Proceedings, 2005 ASEE Annual Conference \& Exposition, Portland, OR, June 2005.

[5] Estell, J., \& Hurtig, J. (2005, June), Truly Interdisciplinary: The Onu Eccs Senior Design Experience, Proceedings, 2005 Annual ASEE Conference \& Exposition, Portland, OR, June 2005. https://peer.asee.org/15206

[6] Criteria for Accrediting Engineering Programs, Effective for Reviews During the 2015-2016 Accreditation Cycle.

http://www.abet.org/wp-content/uploads/2015/05/E001-15-16-EAC-Criteria-03-10-15.pdf

[7] History, ABET, Inc. http://www.abet.org/about-abet/history/

[8] Mellodge, P., \& Folz, D. (2009), A Multiuniversity, Interdisciplinary Senior Design Project In Engineering, Proceedings, 2009 ASEE Annual Conference \& Exposition, Austin, TX. https://peer.asee.org/4576

[9] Sanders, M., \& Thompson, M., \& El-Sayed, M., \& King, L., \& Lindquist, M. (2006), Assessing Interdisciplinary Engineering Capstone Project, Proceedings, 2006 ASEE Annual Conference \& Exposition, Chicago, IL. https://peer.asee.org/695

[10] Digital Battery Analyzer. http://www.harborfreight.com/digital-automotive-battery-analyzer-66892.html

[11] Automatic Battery Float Charger.

http://www.harborfreight.com/automatic-battery-float-charger-42292.html 


\section{Appendix A}

ETEC 4369 Engineering Experimental Projects Student Projects - Time Log Sheet

Semester

Name:

ID:

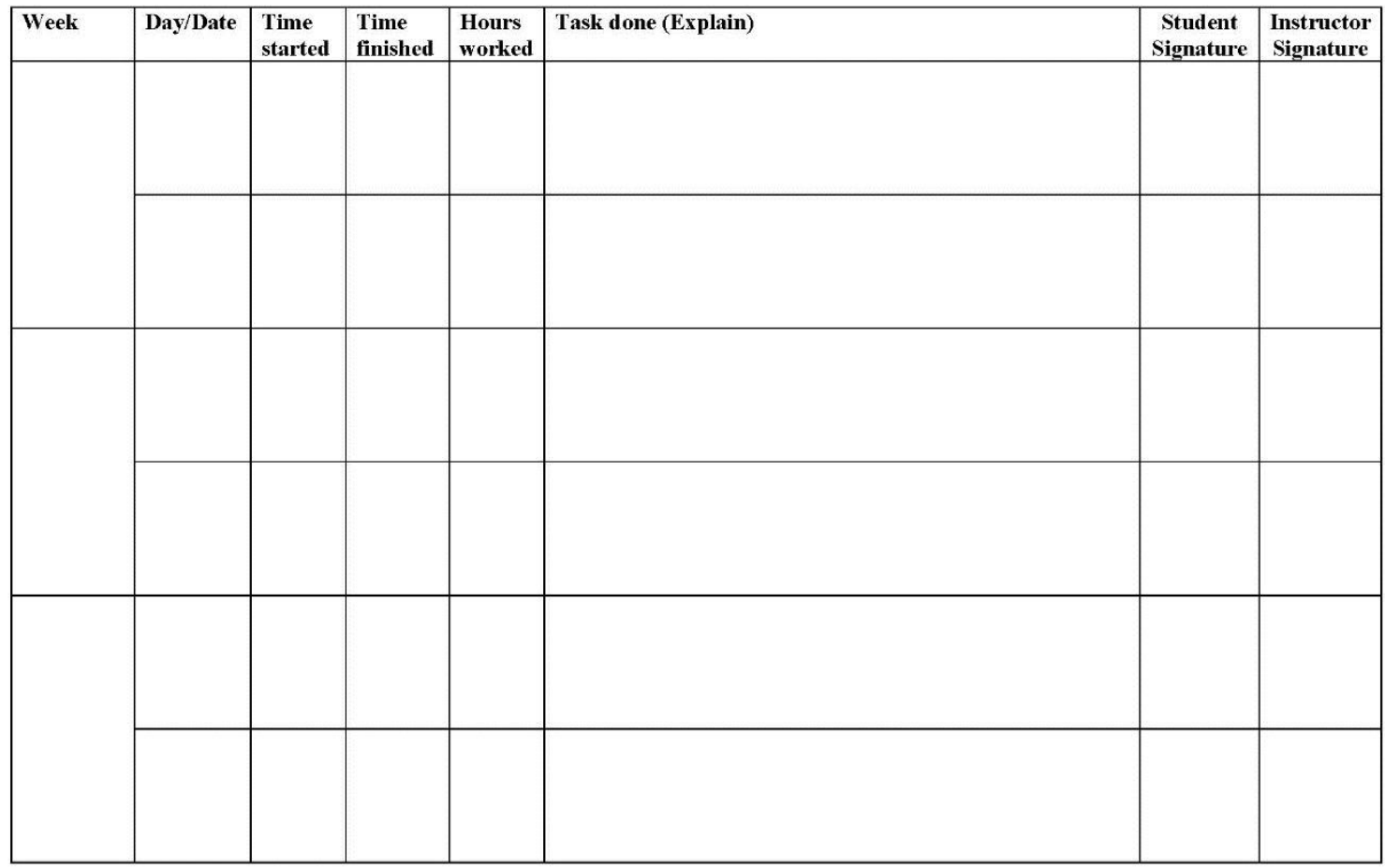




\section{Appendix B}

\section{ETEC 4369 Experimental Engineering Projects}

Scoring Rubric for Project Presentations

Team Members:

Project Title:

\section{PRESENTATION SKILLS}

Poor

$\begin{array}{lllll}1 & 2 & 3 & 4 & 5\end{array}$

Were the main ideas presented in an orderly and clear manner?

Did the presentation fill the time allotted?

Were the overheads/handouts appropriate and helpful to the audience?

Did the talk maintain the interest of the audience?

Was there a theme or take-home message to the presentation?

Were the presenters responsive to audience questions?

, , , ,

., , , ,

Excellent

KNOWLEDGE BASE

Was proper background information on the topic given?

Was the material selected for presentation appropriate to the topic?

Was enough essential information given to allow the audience to effectively ... evaluate the topic?

Was irrelevant or filler information excluded?

Did the presenters have a clear understanding of the material presented?

\section{CRITICL THINKING}

Were the main issues in this area clearly identified?

Were both theoretical positions and empirical evidence presented?

Were the strengths and weaknesses of these theories, and the methods used to .............. gather this evidence adequately explained?

Did the presenters make recommendations for further work in this area?

Did the main conclusions of the presentation follow from the material presented? ..., ,

Were competing explanations or theories considered and dealt with properly? .........,

OVERALL IMPRESSION $/ 15$

\section{COMMENTS}

